\title{
STUDIES ON THE GROWTH OF MARINE PHYTOPLANKTON
}

\section{ISOCHRYSIS GALBANA PARKE}

\author{
By Joanna M. KaIN` and G. E. FogG \\ Department of Botany, University College, London
}

(Text-figs. I-8)

A good deal is known about the growth in culture of Phaeodactylum tricornutum Bohlin (Nitzschia closterium W. Sm. forma minutissima Allen \& Nelson) (see Spencer, 1954; Harvey, 1955; Provasoli, McLaughlin \& Droop, 1957). This organism, however, is a somewhat aberrant member of the Chrysophyta, and other marine and brackish-water representatives of the group, e.g. Syracosphaera carterae Braarud \& Fagerland (Braarud \& Fagerland, 1946; Provasoli, McLaughlin \& Pintner, 1954), Prymnesium parvum Carter (Reich \& Kahn, 1954; Droop, 1954), and certain other species (Droop, I954, I955 $a, b$ ) have been studied much less intensively from this point of view. It has therefore seemed worth while making a general study, similar to that reported in the first paper of this series for the diatom Asterionella japonica Cleve \& Müller ex Gran, of the growth requirements of a representative of the Chrysophyceae. Isochrysis galbana Parke, a flagellate of some importance as a food organism of the oyster, has been selected for this purpose. Johnston (1955) has used unialgal cultures of this species in studies of dissolved organic matter in sea water and, since the investigation being described was carried out, Droop (1957) has reported that it has a requirement for cobalamin.

\section{MATERIALS AND METHODS}

The culture of Isochrysis used was isolated by Dr M. W. Parke from Port Erin fish ponds in 1938 (Parke, 1949). It was obtained from the Plymouth collection shortly after it had been partly freed of bacteria by phototaxis. It was not purified further.

The methods used for the culture and study of this organism were almost the same as those used for Asterionella (see Kain \& Fogg, I958). In stagnant culture a glass bead was included in each boiling tube to help in the removal of cells adhering to the bottom. Media were autoclaved at $15 \mathrm{lb}$. for less than I min instead of for $15 \mathrm{~min}$. The media used were identical to those used for Asterionella, omitting sodium silicate and the buffer. They are denoted AO

* Now at the Marine Biological Station, Port Erin, Isle of Man. 
(similar to $\mathrm{AK}$ for Asterionella), $\mathrm{AQ}_{\mathrm{N}}$ (similar to $\mathrm{AR}_{\mathrm{N}}$ ) and $\mathrm{AQ}_{\mathrm{A}}$ (similar to $\left.A R_{A}\right) . A O$ and $A Q_{N}$, containing natural sea water and soil extract in the case of $\mathrm{AO}$, presumably contained cobalamin though it cannot be certain that the amount of this was always sufficient to maintain the optimum growth of Isochrysis. Vitamins were sometimes added to $\mathrm{AQ}_{\mathrm{A}}$.

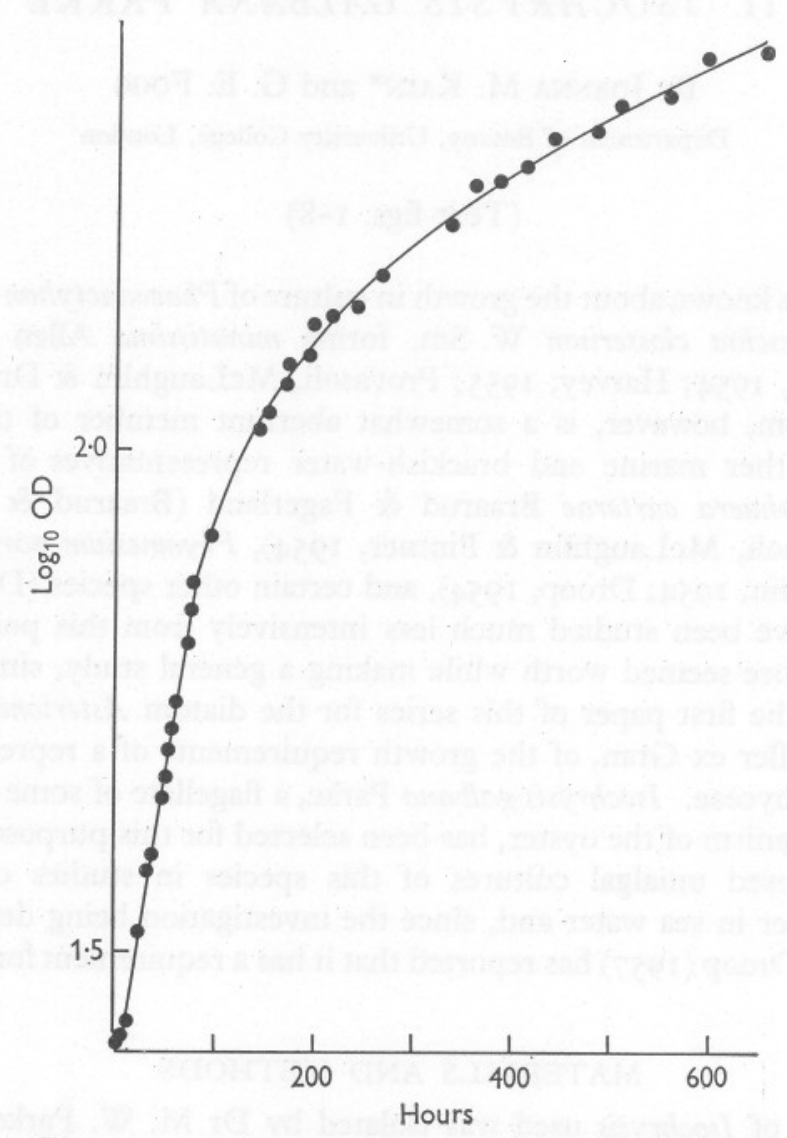

Fig. I. The mean growth curve, determined by optical density readings, of two cultures of Isochrysis.

Growth

EXPERIMENTS

An example of the growth curve of Isochrysis in stagnant Erdschreiber medium is shown in Fig. I. There was normally a lag period of up to $24 \mathrm{~h}$ after which growth was exponential, with a relative growth constant (defined as $\left(\log _{e} N_{t}-\log _{e} N_{0}\right) / t$ in days) of $k=0.25$ to 0.55 . After 100-I50 h growth was limited by the availability of carbon dioxide but continued slowly for up to $500 \mathrm{~h}$, giving final populations of the order of 10,000 cells $/ \mathrm{mm}^{3}$. During the 
growth of Isochrysis in stagnant culture the $\mathrm{pH}$ of the medium rose to a higher level than for Asterionella, $\mathrm{pH} 9$ being exceeded after $400 \mathrm{~h}$.

\section{Nitrogen supply}

Isochrysis was grown in a series of concentrations of potassium nitrate in the artificial sea water medium $\left(\mathrm{AQ}_{\mathrm{A}}\right)$, from an inoculum that had been washed in nitrate-free artificial sea water. Cell counts were made after $700 \mathrm{~h}$ and the cell crop in each culture calculated by subtracting the cell concentration in the controls to which no nitrate had been added from the cell concentration in the culture itself. This is shown plotted against the initial nitrate concentration in Fig. 2, which also gives the quantity of nitrate added to the medium divided by the crop obtained from it. The two lowest concentrations were evidently limiting and in these the mean nitrogen content was $0.0507 \mu \mu$ g-atom N/cell $\left(0.7 \times\right.$ I0 $^{-9} \mathrm{mg} \mathrm{N} /$ cell).

\section{Phosphorus supply}

An analogous experiment on the phosphorus requirement was made with a series of concentrations of dipotassium hydrogen phosphate. The results are shown in Fig. 3. The mean quantity of phosphorus in the cells in the lowest three concentrations, where it was limiting, was $0.000972 \mu \mu \mathrm{g}$-atom $\mathrm{P} /$ cell (0.03 $\times 10^{-9} \mathrm{mg} \mathrm{P} /$ cell).

\section{Salinity}

The relative growth constant of Isochrysis in natural sea water was reduced to 0.27 at $10 \% \mathrm{~S}$ but showed no statistically significant deviation from a mean value of 0.36 over the range $15-40 \% \mathrm{~S}$.

\section{Artificial sea water}

In medium $\mathrm{AQ}_{\mathrm{A}}$, composed principally of the major constituents of sea water and the trace elements with EDTA as used by Provasoli et al. (1957), the growth of Isochrysis was normal only when soil extract was present. This may be at least partly explained by its requirement for cobalamin. Unpublished work by Miss S. Arregger has shown that Isochrysis grows well in a synthetic medium, $\mathrm{S}_{50}$ of Droop (1958), in which $0.25 \mathrm{~g} / 1$. of glycylglycine seems to be an important component.

\section{Temperature}

The relative growth constants at different temperatures in medium $\mathrm{AO}$, expressed as percentages of the mean of those of control cultures at $25^{\circ} \mathrm{C}$, are plotted in Fig. 4. Between $20^{\circ}$ and $25^{\circ} \mathrm{C}$ was optimal; at $30^{\circ} \mathrm{C}$ no growth 


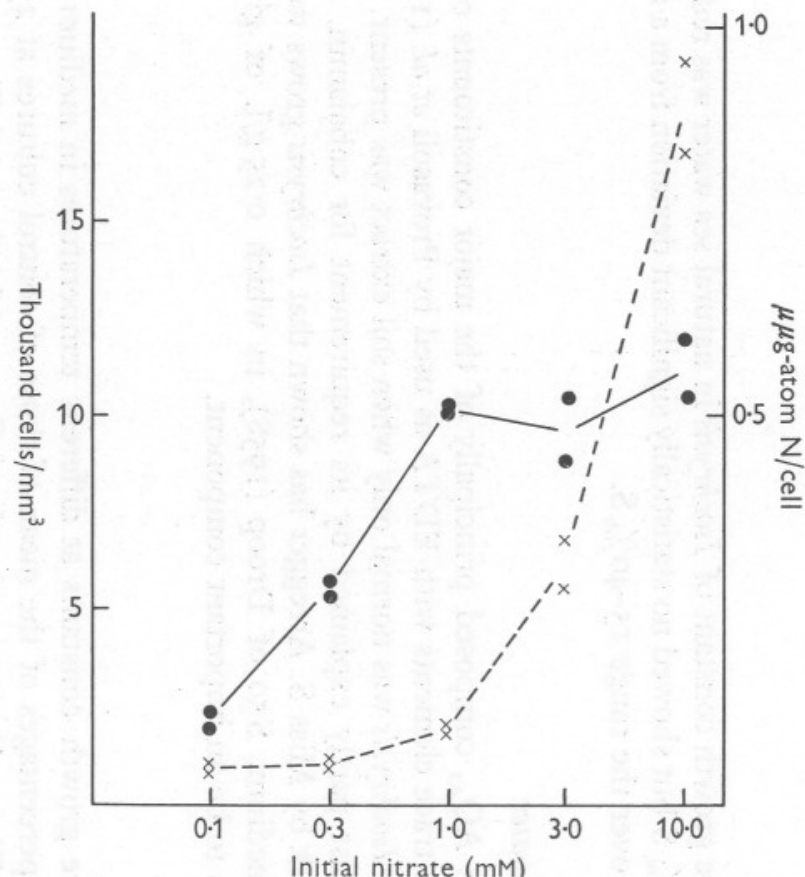

Fig. 2. The cell crop and nitrogen per cell of Isochrysis in relation to concentration of potassium nitrate. - - cell crop; -- $\times---\times--$, nitrogen/cell.

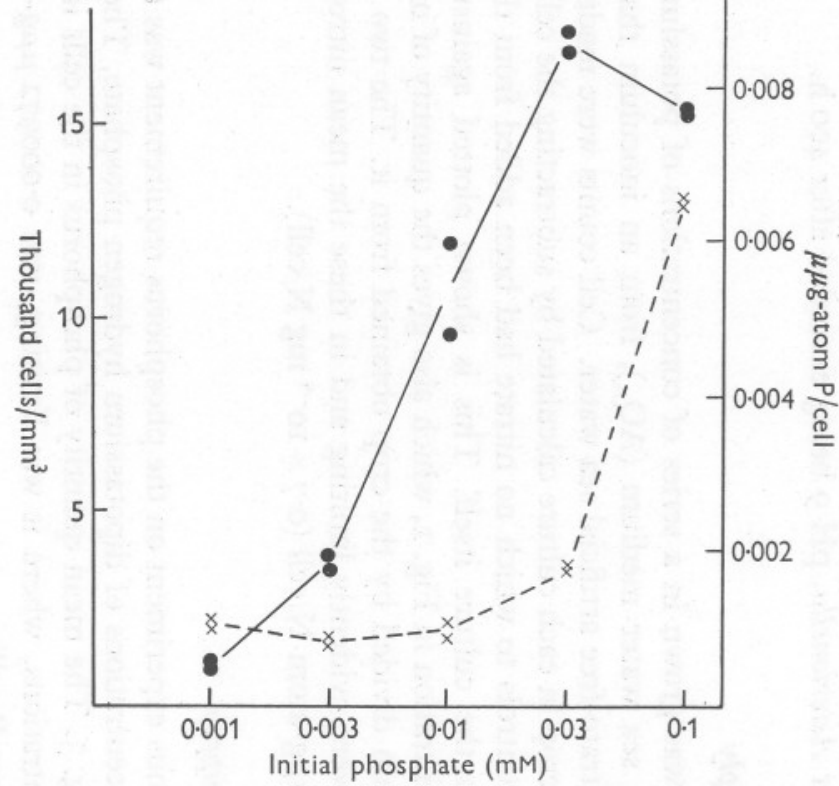

3

Fig. 3. The cell crop and phosphorus per cell of Isochrysis in relation to concentration of dipotassium hydrogen phosphate. $-1-$, cell crop; -- $\times---\times--$, phosphorus/cell. 
took place, but exposure for a week to this temperature was not lethal as cultures returned to $20^{\circ} \mathrm{C}$ were able to grow.

\section{Light}

The results of two experiments to determine the relative growth constants at various light intensities in medium $A_{\mathrm{N}}$ are shown in Fig. 5. Saturation was reached at about 1500 lux, an intensity of the same order as that saturating

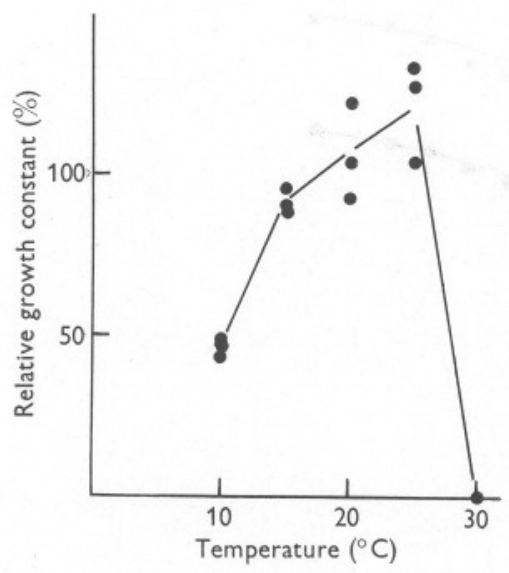

Fig. 4

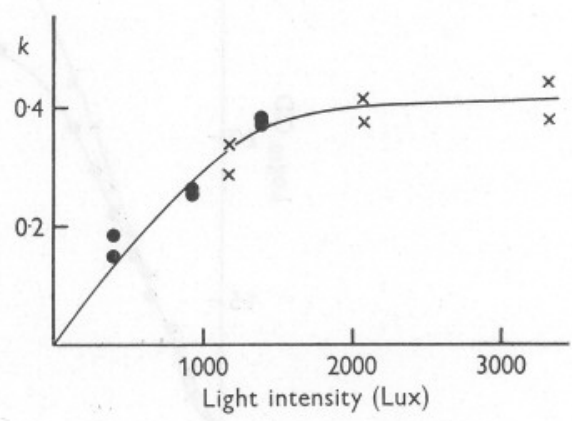

Fig. 5

Fig. 4. The relative growth constant, as \% of controls, of Isochrysis at different temperatures. (See text for further explanation.)

Fig. 5. The relative growth constant $(k)$ of Isochrysis in different intensities of fluorescent light. -, Expt. $\mathrm{I} ; \times$, Expt. 2.

for the growth of Chlorella pyrenoidosa (Myers, 1953); there was no inhibition at 3000 lux. In both experiments the optical density per cell at the end of the exponential phase was considerably lower at higher than at lower light intensities.

\section{Aeration}

The mean growth curves of triplicate aerated and stagnant cultures in medium $\mathrm{AQ}_{\mathrm{A}}$ are shown in Fig. 6. The mean relative growth constant was higher under aerated $(0.526 \pm 0.025)$ than under stagnant $(0.446 \pm 0.026)$ conditions, but the difference between the values was scarcely statistically significant at the $5 \%$ level. It is clear, however, that growth at the initial rate was continued to a much higher cell concentration (about I4,000 cells/ $\mathrm{mm}^{3}$ ) under aerated than under stagnant conditions (about $6000 \mathrm{cells} / \mathrm{mm}^{3}$ ). A final population of 24,000 cells $/ \mathrm{mm}^{3}$ was attained in aerated culture on occasion. 


\section{Hydrogen-ion concentration}

In determining the optimum $\mathrm{pH}$ for the growth of Isochrysis it was not possible to use the buffer tris(hydroxymethyl)aminomethane at a really effective concentration as this was inhibitory (see below). Instead $\mathrm{I} .65 \mathrm{~mm}$ of tris was used and daily adjustments made to the $\mathrm{pH}$ of the medium $\left(\mathrm{AQ}_{\mathrm{A}}\right)$, by means of the dummy tube method previously described (Kain \& Fogg,

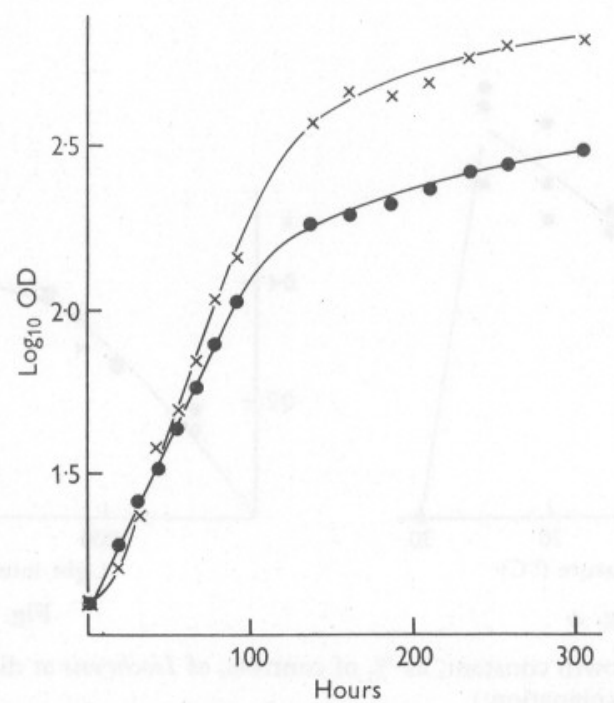

Fig. 6. The growth curves, determined from optical density readings, of Isochrysis in stagnant and aerated culture.

$-0-$, stagnant; -- $\times---\times--$, aerated.

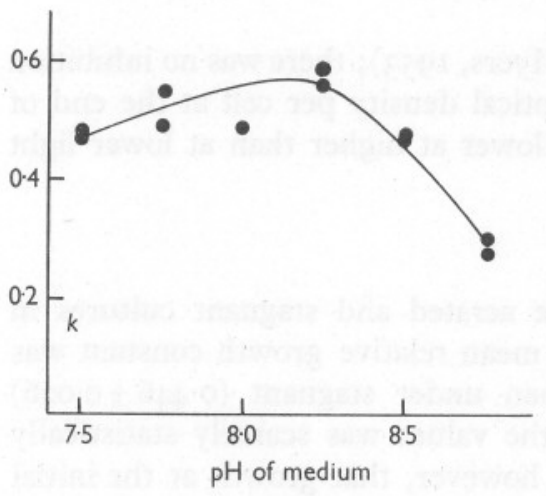

Fig. 7

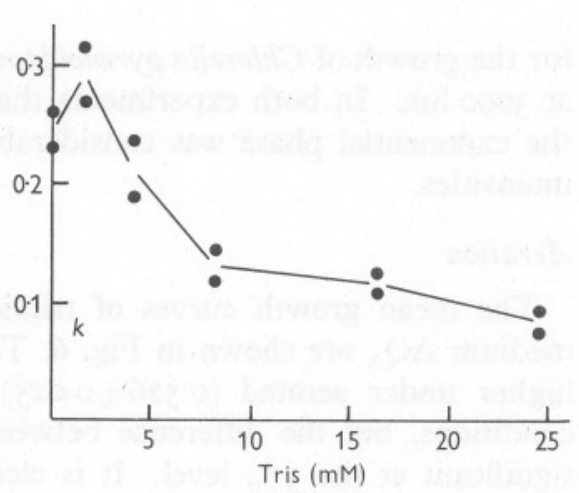

Fig. 8

Fig. 7. The relative growth constant ( $k$ ) of Isochrysis in media adjusted to various pH's.

Fig. 8. The relative growth constant (k) of Isochrysis in relation to concentration of the buffer tris. 
1958). The maximum variation observed was $0.3 \mathrm{pH}$ units at $\mathrm{pH} 7.5$. It was mostly about $\mathrm{O} \cdot \mathrm{I} \mathrm{pH}$ unit. The $\mathrm{pH}$ of each experimental tube was determined at the end of the exponential phase and found not to differ by more than $0.12 \mathrm{pH}$ units from that of the corresponding dummy tube. The relative growth constants are shown in Fig. 7. There was clear inhibition at $\mathrm{pH} 8.75$ only.

The relative growth constants in a range of tris concentrations are shown in Fig. 8. There was a marked inhibition at $8.25 \mathrm{~mm}$ and above. The difference between the $k$ values for $\mathrm{I} .65 \mathrm{mM}$ and for the controls is not statistically significant. In a further experiment using triplicate cultures $k$ values of $0.446 \pm 0.026$ and $0.446 \pm 0.017$ were obtained for control and $\mathrm{I} .65 \mathrm{mM}$ tris cultures respectively. It therefore appears that low concentrations of tris have no appreciable stimulatory effect on Isochrysis. The marked inhibition of the growth of Isochrysis in $8.25 \mathrm{mM}$ of tris shows that this organism differs from those tried by Provasoli et al. (1957) which were all tolerant of 0. I \% $(8.25 \mathrm{mM})$ of the buffer.

These results will be discussed together with those for other species on a later occasion.

This work has been carried out under extra-mural contract with the Institute of Seaweed Research. We are grateful to the Institute for a maintenance grant made to one of us (J.M.K.). We are also grateful to Dr M. W. Parke for the culture of Isochrysis and for helpful suggestions.

\section{SUMMARY}

The flagellate Isochrysis galbana has been grown in unialgal culture under controlled conditions and its growth has been measured by means of optical density determinations and cell counts.

The relative growth constant has been found to be $0.55 \log _{e}$ units per day under optimum conditions. Waters with salinities from 15 to $40 \% \mathrm{~S}$ supported rapid growth. The optimum temperature was $20^{\circ}$ to $25^{\circ} \mathrm{C}$ and the optimum light intensity from I500 to at least 3000 lux. The rate of growth was inhibited at $\mathrm{pH} 8.75$ and above. The buffer tris(hydroxymethyl)aminomethane had an inhibitory effect at concentrations of $8 \mathrm{~mm}$ and above. Final yields of the order of 24,000 cells $/ \mathrm{mm}^{3}$ could be obtained in cultures aerated by bubbling air. The minimum nitrogen requirement per cell was $0.0507 \mu \mu \mathrm{g}-$ atom $\mathrm{N} /$ cell and the minimum phosphorus $0.000972 \mu \mu \mathrm{g}$-atom P/cell. 


\section{REFERENCES}

BRAARUD, T. \& FAgERLAND, E., I946. A coccolithophoride in laboratory culture. Avh. norske VidensAkad., I946, No. 2.

Droop, M. R., 1954. Cobalamin requirement in Chrysophyceae. Nature, Lond., Vol. 174, p. 520.

_ 1955a. Some new supra-littoral protista. F. mar. biol. Ass. U.K., Vol. 34, pp. 233-45.

- $1955 b$. A suggested method for the assay of vitamin $\mathrm{B}_{12}$ in sea water. F. mar. biol. Ass. U.K., Vol. 34, pp. 435-40.

- 1957. Auxotrophy and organic compounds in the nutrition of marine phytoplankton. F. gen. Microbiol., Vol. I6, pp. 286-93.

- 1958. Requirement for thiamine among some marine and supra-littoral protista. F. mar. biol. Ass. U.K., Vol. 37, pp. 323-29.

Harvey, H. W., 1955. The Chemistry and Fertility of Sea Waters. Cambridge University Press.

Johnston, R., 1955. Biologically active compounds in the sea. F. mar. biol. Ass. U.K., Vol. 34, pp. 185-95.

KAIN, J. M. \& FoGG, G. E., 1958. Studies on the growth of marine phytoplankton. I. Asterionella japonica Gran. F. mar. biol. Ass. U.K., Vol. 37, pp. 397-4I3.

MYERS, J., I953. Growth characteristics of algae in relation to the problems of mass culture. In Algal Culture from Laboratory to Pilot Plant, editor J. S. Burlew, Carnegie Institution of Washington publication, No. 600, pp. 37-54.

PARKe, M. W., 1949. Studies on marine flagellates. F. mar. biol. Ass. U.K., Vol. 28, pp. $255-85$.

Provasoli, L., Mclaughlin, J. J. A. \& Droop, M. R., 1957. The development of artificial media for marine algae. Arch. Mikrobiol., Bd. 25, pp. 392-428.

Provasoli, L., Mclaughlin, J. J. A. \& Pintner, I. J., I954. Relative and limiting concentrations of major mineral constituents for the growth of algal flagellates. Trans. N.Y. Acad. Sci., Vol. 16, pp. 412-17.

ReICH, K. \& KAHN, J., I954. A bacteria-free culture of Prymnesium parvum (Chrysomonadina). Bulletin of the Research Council of Israel, Vol. 4, pp. I44-49.

SPENCER, C. P., 1954. Studies on the culture of a marine diatom. F. mar. biol. Ass. U.K., Vol. 33, pp. 265-90. 